\title{
TRIAL OF IMCI ALGORITHM IN DISEASE DETECTION CARD IN BEHAVIOR OF CHILDREN IN HAJRAN VILLAGE, BATIN XXIV SUBDISTRICT BATANGHARI DISTRICT JAMBI
}

\author{
M. Dody Izhar \\ Faculty of Public Health Jambi University \\ E-mail : mdodyizhar@yahoo.com \\ Hubaybah \\ Faculty of Public Health Jambi University \\ E-mail : beebeeideh@gmail.com \\ Ruwayda \\ Jambi Health Polytechnic Ministry of Health of the Republic of Indonesia \\ E-mail : ida_dodyrz@yahoo.co.id
}

\begin{abstract}
Integrated Management of Childhood Illness (IMCI) is one of management strategies for sick toddlers, in the form of curative and preventive efforts in order to overcome the toddler's health problems in the Suku Anak Dalam (SAD) in Jambi Province.

The study uses a quasy experiment design. The research sample consisted of 11 parents of toddlers (15 years old) Tribe of Children in the Village of Hajran in the working area of Puskesmas Durian Luncuk, Batin XXIV Sub-District, Batanghari District, Jambi, taken by total sampling technique. Statistical analysis with the significance level of the test $p<0,05$.

The results of the study revealed that the detection card for 1-5 year old children is a valid instrument $\left(\mathrm{r}_{\text {test }}\right.$ : $\left.0,564-0,814>r_{\text {table }}: 0,444\right)$ and reliable $\left(r_{\text {test }}: 0,765\right)$ in detecting the symptoms of the disease. Based on the analysis of paired samples $T$ test it is known that there is a difference in knowledge before $(\overline{\mathrm{x}}=6,45)$ with after $(\bar{x}=10,18)$ treatment, thus there is a significant influence $\left(\overline{\mathrm{x}}=3,73, \mathrm{t}_{\text {test }}=5,632, \quad p_{\text {Value }}=0,000\right)$ knowledge of people Suku Anak Dalam parents with the use of detection cards for toddlers.

The study concluded that the detection card for diseases of infants (IMCI algorithm) is a valid and reliable instrument, and there was a significant effect of treatment with the IMCI algorithm on the knowledge of Suku Anak Dalam parents in Hajran Village, Batin XXIV Sub-District, Batanghari District Jambi. It is hoped that this research can be used as a guide in the prevention and control of diseases.
\end{abstract}

Keywords: Knowledge, IMCI, SAD

\section{INTRODUCTION}

The problem of children's health is one of main problems in health sector. Child health degrees reflects to degree of health nation, cause children as successor of nation have the capability in continued nation development. Based on these reasons, the problem of children's health a priority in planning and development of nation. ${ }^{1}$
The mortality children under five years age rate in world is still quite high, each year 6.6 million children under five years age died, 18,000 died almost every day. Most of children under five years age deaths are in developing countries, more than half of it due to acute respiratory tract infections (pneumonia), diarrhoea, measles, malaria, and HIV/AIDS. In addition malnutrition (54\%) underlying all the deaths of child. Globally, in the year 2020 these diseases will contribution main causes death of children in the world. Thus, efforts are constantly made to control it with integrated management children under five years age sick program, where in Indonesia named MTBS program (Manajemen Terpadu Balita Sakit) ${ }^{2}$

Although there is an increase in programmes to addressing the problem of disease, the number of mortality and morbidity still remain high, a variety of innovative ways to reduce mortality and morbidity rate in children starting from pregnancy continue to be developed. The strategy of integrated management children under five years age sick program include curative and preventive efforts to increase improvement in health systems, case management, and health practices by families and communities. ${ }^{1}$

Integrated management children under five years age sick program activities have three typical components that benefit, like improving health worker skills in corporate governance children under five years age sick case, improve health systems, and improve practices in households and communities in home care and search efforts on the case children under five years age sick treatment. ${ }^{2}$

Each year more than ten million children in the world die before reaching age of 5 years. More than half of which are caused by five conditions that actually can be prevented and treated, such as pneumonia, diarrhea, malaria, measles and malnutrition. Often combined from several other diseases. $^{3}$

Integrated management children under five years age sick program activities is an effort aimed to 
lowering number of morbidity and mortality rate while enhancing quality of health services in basic health outpatient units such as community health centers. ${ }^{4}$

Most disease in children under five years age can be done corporate governance with integrated management children under five years age sick program activities is a disease that is the leading cause of death such as pneumonia, diarrhea, malaria, measles and conditions in add by nutritional problems (malnutrition and anemia). Integrated management children under five years age sick program approach steps is to use simple algorithms used by nurses and midwives in order to overcome the problem of pain in children under five years age. Integrated management children under five years age sick is a cost effective interventions to address mortality children under five years age problems caused by acute respiratory tract infections, diarrhoea, measles, malaria, and malnutrition which is often a combination of these circumstances. $^{5}$

Acute respiratory tract infections themselves had dubbed as main killer of infant mortality as well as children under five years age in Indonesia. According data Batang Hari of District Health Office acute respiratory tract infection is most disease in 10 of biggest disease in children under five years age. A case of pneumonia on children under five years age was recorded as much as $24.61 \%$ in 2016, and ever experienced extraordinary occurrence of measles in $2012 .^{6}$

One of work areas Durian Luncuk community health center is Batin village. Most of inhabitants are isolated tribes in Jambi province in name Suku Anak Dalam (SAD) or Kubu people or Rimba people. The data recorded in Batin Subdistrict as much as 70 household are Suku Anak Dalam (SAD) or Kubu people or Rimba people. Most types of diseases that plagued by Kubu people such as coughing, diarrhea, malaria and malnutrition .

Different types of disease in children under five years age can be prevented by implementing one of government's programs in coping diseases at children under five years age with integrated management children under five years age sick programme. These activities include assessment, classification, and actions including advice to mothers in form of counselling and follow-up, so that does not occur in morbidity and mortality on children under five years age. ${ }^{8}$

Based on above problems then researchers interested in conducting research with title research Algorithms Tests at Integrated Management children under five years age sick programme with Disease Detection cards on children under five years age Suku Anak Dalam at Hajran Village Batanghari sub district Jambi province.

\section{RESEARCH METHODS}

This research is analytical research with quasy experiment two group pre and post test design 9 Aiming research to find out influence Algorithms Tests at Integrated Management children under five years age sick programme with Disease Detection cards on children under five years age Suku Anak Dalam at Hajran Village Batin XXIV sub district Batanghari district Jambi province. The research was carried out on Suku Anak Dalam at Hajran Village Batin XXIV sub district Batanghari district Jambi province Jambi province starting from March until October 2018.

The population in this study are parents of children under five years age (1-5 years old) who are in Suku Anak Dalam (SAD) group Desa Hajran working area Durian Luncuk community health center Batin XXIV sub district Batanghari district Jambi province. Number of population as much as 11 people ${ }^{10}$. Number of samples as much as 11 people. Samples taken with Total sampling. ${ }^{11}$

Instruments used on this research are integrated management children under five years age sick format and knowledge Questionnaire of integrated management children under five years age sick developed by Ministry of health of Indonesia as well as Disease Detection Cards on children under five years age (MTBS Algorithm), ${ }^{8}$ Detection of disease in Suku Anak Dalam (SAD) children under five years age, developed by researcher (valid) $\left(r_{\text {test }}: 0,564-0,814\right.$ $\left.>r_{\text {table: }} 0,444\right)$ dan reliabel (rtest: 0,765$)$ ).

\section{RESULTS AND DISCUSSION}

\section{Research Results}

\section{The characteristics of subject}

The characteristics of subject shows that proportions of sex women subject more than men subject that is 7 people (63.63\%), whereas the characteristics of age, weight and height of subject in outline presented in following table 1:

Table 1. Characteristics of respondents according to age, weight and Height

$(\mathrm{N}$ Total $=11$ subjek $)$

\begin{tabular}{llccc}
\hline Subject characteristics & Min & Max & Mean \pm SD \\
\hline 1 Age (year) & 3 & 5 & $3,91 \pm 0,83$ \\
2 & Body weight $(\mathrm{kg})$ & 12 & 18 & $12,86 \pm 2,67$ \\
3 & Height $(\mathrm{cm})$ & 70 & 100 & $82,27 \pm 11,94$ \\
\hline
\end{tabular}

\section{Disease Detection Cards}

From 10 classification at instruments known 10 classification stated valid because $\mathrm{r}$ count $=0,564$ 0,814 larger than $r$ tables at 5\% significant level with $r$ $=0.444$ table. From calculations undertaken also obtained the value $r$ as much as 0.765 . Then it can be inferred that Detection diseases card instrument (MTBS) in children under five years age is reliability 
with strong criteria. Reliability and validity of test results may be submitted as follows:

Table 2. The results of Test Validity and Reliability of instruments

\begin{tabular}{llccc}
\hline \multicolumn{1}{c}{ Classification } & $\boldsymbol{r}_{\text {test }}$ & $\boldsymbol{r}_{\text {table }}$ & Conclusion \\
\hline 1. General danger sign & 0,564 & 0,444 & \\
2. Caugh are difficult to breathe & 0,695 & 0,444 & \\
3. Diarrhea & 0,730 & 0,444 & \\
4. Fever & 0,660 & 0,444 & \\
5. Malaria & 0,693 & 0,444 & Valid \\
6. Measles & 0,633 & 0,444 & \\
7. Dengue fever & 0,807 & 0,444 & \\
8. Ear Infection & 0,611 & 0,444 & \\
9. Nutritional status & 0,814 & 0,444 & \\
10. Anemia & 0,589 & 0,444 & \\
\hline \multicolumn{2}{c}{ Instrument } & Reliability & Conclusion \\
\hline \multicolumn{2}{c}{ value } \\
\hline Detection diseases card instrument & 0,765 & Reliable \\
\hline
\end{tabular}

\section{Results of pre test and post test knowledge}

Frequency distribution score Pre-test class experiments can be seen from following table:

Table 3. Parents Knowledge Test results before (Pre-test) and after (Post-test) treatment

\begin{tabular}{|c|c|c|c|}
\hline & & $\begin{array}{c}\text { Pre-test } \\
\text { Knowledge }\end{array}$ & $\begin{array}{c}\text { Post-test } \\
\text { Knowledge }\end{array}$ \\
\hline \multirow[t]{2}{*}{$\mathrm{N}$} & Valid & 11 & 11 \\
\hline & Missing & 0 & 0 \\
\hline \multicolumn{2}{|c|}{ Mean } & 6.45 & 10.18 \\
\hline \multicolumn{2}{|c|}{ Median } & 7.00 & 10.00 \\
\hline \multicolumn{2}{|c|}{ Mode } & 5 & 8 \\
\hline \multicolumn{2}{|c|}{ Std Deviation } & 1.809 & 2.228 \\
\hline \multicolumn{2}{|c|}{ Minim um } & 3 & 7 \\
\hline \multicolumn{2}{|c|}{ Maximum } & 9 & 14 \\
\hline
\end{tabular}

The results of calculations with statistical analysis software note that the average score of knowledge after more increased $(3.73 \pm 2.23)$, this data shows that there is a difference between increasing parents knowledge towards early detection of illness experienced by their children.

\section{Testing Requirements Analysis}

Testing prerequisites analysis done before performing data analysis. Prerequisites which are used in this research is homogeneity and normality test. Analysis prerequisite test results are presented in following:

\section{a. Uji Normalitas Test For Normality}

Normality data test results note that data pre-test and post-test results of knowledge has value sig $>0.05$, It can be concluded that group data normal distribution. Test results presented in following table:

Table 4. Normality Test Summary

\begin{tabular}{cccc}
\hline No & Knowledge & Sig. & Conclusion \\
\hline 1. & Pre-test & 0,466 & Normal \\
\hline 2. & Post-test & 0,788 & \\
\hline
\end{tabular}

\section{b. Homogeneity Test}

Results of homogeneity test research variables known value $F$ count of 0.588 significantly 0.452 . From results of calculation of significant knowledge data (pre-test or post-test) is greater than 0.05 (sig>0.05), then it can be inferred that data in this study have a variance homogeneity. The results of analysis presented in following table :

Table 5. A Summary Of Homogeneity Test

\begin{tabular}{lccc}
\hline \multicolumn{1}{c}{ Variable } & $\mathbf{F}_{\text {test }}$ & Sig. & Conclusion \\
\hline $\begin{array}{l}\text { Knowledge } \\
{[\text { Pre-test \& Post-test }]}\end{array}$ & 0,588 & 0,452 & Homogeneity \\
\hline
\end{tabular}

\section{The results of analysis}

The t-test analysis before and after treatment aims to find out whether there is an increase in score. Conclusion the study revealed significant when $t$ calculate $>t$ tables at 5\% significance level and value of $p<0.05$. As for the summary of test t pre-test and post test experimental class shown in following table:

\section{Table 6. The paired t test results summary Pre-test with Post-test}

\begin{tabular}{lcccc}
\hline Experiment & Mean & $\mathbf{t}_{\text {test }}$ & $\mathbf{t}_{\text {table }}$ & $\boldsymbol{p}_{\text {value }}$ \\
\cline { 1 - 2 } Pre-test & 6,45 & \multirow{2}{*}{5,632} & 2,228 & 0,000 \\
\hline Post-test & 10,18 & & & \\
\hline
\end{tabular}

Based on the results of test $t$ known average pretest of 6.45 at time of post-test increase to 10.18 , making its increase of 3.73. Furthermore based on a test $\mathrm{t}$ obtained $\mathrm{t}$ count of 5.632 significance with 0.000 . The value of $\mathrm{t}$ tabel pada $(d f: \mathrm{n}-\mathrm{k})=10$, with $5 \%$ significance level is 2.228 . So value $t_{\text {hitung }}>t$ tabel $(5,632>2,228)$ and their significance value less than $0.05(\mathrm{p}=0.000<0.05)$. From the data above, it can be concluded that an increase of 3.73 or there is increased significantly on the score of knowledge of respondents.

\section{Discussion}

Organization of health services with an integrated management children under five years age sick programme approach to community-based are applied to difficult areas access in the district/city. With the focus of activities for health promotion behavior to search aid health, children under five years age home care and training to community members. In some parts of Indonesia number of health care personnel resources are still limited and its uneven, a comparison between the basic health care facilities with a number of health workers is still not appropriate, this led to health service cannot run continuously. Many areas that have not been estimated operational costs as well as provision of sufficient logistics to be able to support basic health services for children and mothers are routinely. ${ }^{8}$

Community groups with socio-cultural barriers and socioeconomic and sosiokultural constraints 
causing parents to be less knowledgeable about health services especially for children under five years age. On community groups who live sedentary on this group much needed cross-sector engagement, anthropologist, community organizations, public figures including religious figures and customs in order to approach, education and dissemination of information about health services. ${ }^{8}$

In Indonesia many areas that are hard to reach by regular medical services basic such as mountainous regions, inland and swamps, small islands, a cluster of Islands and coastal areas, border areas. Other obstacles due to condition availability of public transportation and a routine that is used both by land, sea or air (only 1 time a week), travel time round trip takes more than 6 hours, only available trasnportasi that existed at any time and no public transportation available. This difficult areas there may be facilities health service but without professionals resource and infrastructure is very minimal or indeed location is very far from population. $^{8}$

Organizing integrated management children under five years age sick programme communitybased aims to improve access children under five years age sick programme service at community level in difficult access areas to health services. The difficult access area in question is community groups that do not get a sustainable healthcare resources, community groups with constraints of socio-cultural and community groups by geographical, transport and season constraints. ${ }^{12}$

Hasil penelitian menunjukkan bahwa faktor komunikasi, sumber daya, predisposisi dan struktur birokrasi mempengaruhi implementasi program manajemen terpadu balita sakit di pusat kesehatan masyarakat wilayah Pasuruan The results showed that communication factor, resources, predisposing and bureaucratic structure affects implementation of integrated management children under five years age sick programme in community health centre Pasuruan region. The officer who served children under five years age sick not yet support successful achievement of objectives integrated management children under five years age sick programme because not all officers get integrated management children under five years age sick programme training, number of officers who are not proportional to number of children under five years age sick visit. All health officers integrated management children under five years age sick programme had a positive attitude to support integrated management children under five years age sick programme though already available Standard Operational Procedures (SOP) but not all officers to use them in service of integrated management children under five years age sick programme. The construction of health service is not done routinely, supervision are still common and no follow-up given. ${ }^{13}$

The results of other studies suggests that implementation of an integrated management children under five years age sick programme can give impact to the level of children under five years age health, due to early parents can recognize early symptoms of onset disease. Application of integrated management children under five years age sick programme strategy can be used as a way to make a concerted effort to prevention and disease control. ${ }^{14}$

The results showed have difference in knowledge of respondent before and after treatment with a mean average: 3.73 . This research is not in line with other studies suggesting that there is no meaningful relationship between the variables were tested by behavior of officers in implementation of an integrated management children under five years age sick programme. Knowledge is basis for formation of one's actions. The existence of variation knowledge indicates knowledge of someone affected by a variety of factors among other levels of education, information, culture, experience and social economy. The lack of a relationship between knowledge with the implementation of integrated management children under five years age sick programme due to knowledge does not always change the mindset of person's behavior. ${ }^{15}$

Thus the given treatment Disease Detection Cards on children under five years age (1-5) very influential towards knowledge of parents against symptoms of disease in order to early detection of diseases.

\section{CONCLUSION}

The algorithm implementation of integrated management children under five years age sick programme for Suku Anak Dalam (SAD) or Kubu people or Rimba people in Hajran village Batin XXIV sub-district Batang Hari district Jambi Province can run well marked with Disease Detection Card instrument on children under five years age very valid and reliability. There is influence of the treatment card early detection of disease in children under five years age (integrated management children under five years age sick programme algorithms) to knowledge of Suku Anak Dalam (SAD) parents in Hajran village Batin XXIV sub-district Batang Hari district Jambi Province. To a later date in order to be alert (early detection) when their children is experiencing symptoms of certain diseases.

\section{ACKNOWLEDGEMENT}

For this moment the researchers many thanks to Rector of Jambi University has given permission and funds research sourced from Funds DIPA-PNBP number: 042.01.2.400950/2018.

\section{REFERENCE}

1. Hidayat, 2008. Introduction to Child Health for Midwifery Education. Salemba Medika, Jakarta

2. WHO, 2012. Handbook IMCI Integrated management of Childhood illness. WHO Library 
3. Soenarto, 2009. Organizational Basics. Yogyakarta: Gadjah Mada University Press

4. Prasetyawati, Eka Arsita, 2012. Maternal and Child Health (MCH) in the Millennium Development Goals (MDGs). Yogyakarta: Nuha Medika

5. Kementerian Kesehatan RI, 2011. Integrated Management of Childhood Illnesses (IMCI). http://.www.gizikia.depkes.go.id

6. Dinas Kesehatan Kabupaten Batanghari, 2016. Batanghari District Health Profile 2016. Jambi.

7. Dinas Sosial, Tenaga Kerja \& Transmigrasi Propinsi Jambi, 2010. Profile of Remote Indigenous Community (KAT) KAT Empowerment Program in Jambi Province. Dinas Sosial, Tenaga kerja \& Transmigrasi: Jambi.

8. Kementerian Kesehatan RI, 2014. Guidelines for Implementing Integrated Management of Community-Based Illnesses (MTBS-M). Direktorat Bina Gizi dan KIA Kemenkes RI, Jakarta

9. Gordis, L. 2000. Epidemiology. WB Saunders Company. Philadelphia, PA.

10. Pemerintah Desa Hajran, 2018. Profile of Hajran Village, Batin District XXIV, Batang Hari Regency. Jambi

11. Arikunto, 2006. Statistics for Research. Jakarta : AlfaBeta.

12. Winch, PJ et al, 2002. An Implementation Framework for Houshold and Community Integrated Management of Chilhood Illness. Journal Health Policy Plan, Des17(4):345-53.

13. Nikmatul F, Sudiro dan Atik Mawarni, 2013. Implementation of Integrated Childhood Illness Management (IMCI) Program in the Pasuruan District Health Center. Jurnal Manajemen Kesehatan Indonesia Volume 01 April 2013

14. Armstrong Schellenberg et al, 2004. The Effect of Integrated Management of Childhood Illness on Observed quality of care of under-fives in Rural Tanzania. Health Policy Plan Journal, edition jan:19(1):1-10.

15. Dalglish, Sarah, 2018. Methods For The Strategic Review of Programmes For Integrated Management of Chilhood Illness and community Cases. Journal BMJ; 2018:362 